\title{
TURKEY'S MEMBERSHIP BID TO THE EUROPEAN UNION
}

This paper presents a brief overview of the EU accession process and Turkey's path to EU membership. The aim of the study is to provide a status report on Turkey's accession negotiations. The researcher here asks some questions to shed light on this case, which is still pending. We have looked into the significant reasons for Turkey to seek joining the European Union, the causes of the repeated refusal of the European Union, the internal Turkish reaction, the external alternatives that the Turkish side has resorted to and the future of Turkey's EU membership bid.

Key words: further enlargement of EU, reforms, Turkey, European Union

\section{Introduction}

Regarding the membership problems in the EU, we should indicate that there have been individual cases that have changed the course of the EU membership joining history, and here the researcher has chosen one of these cases, the case of Turkey, as an example which deserves to be studied and analyzed.

Despite the standstill in Turkey and the EU's accession negotiations, the situation has moved on during the past seventy years. Turkey has been seeking to gain accession to the EU since 2005, but its EU membership bid has been refused by France and Germany, so today's status quo carries the day. For Turkey, the advantages of membership are abundantly clear and certainly worth pursuing. The leading concern of most European nations regarding Turkey is its financial status and government policies. That is the official remark regarding Turkey's possible status in the European Union. Of course, there is also a racial and cultural aspect that is often brushed aside. Turkey is going through a comprehensive political and economic transformation.

Significant reforms are being introduced in order to attain the highest norms and standards in the field of democracy, the rule of law and human rights. The Turkish external alternatives are found in forming alliances with the US, the Arab World, Israel and former Soviet Republics. It is a fact that a vast majority of the selected EU countries will vote against Turkey's accession to the EU, but of course, nobody can foresee the situation in a few decades from now.

Dakheel, A. Salem, PhD Candidate, Faculty of International Economics, John Naisbitt University, (Megatrend University), Belgrade, e-mail: deda_20900@yahoo.com. 


\section{Turkey's membership}

The European Community for Coal and Steel was originally founded by six western European states in 1952. The founding members of the Community were France, West Germany, Italy, Belgium, the Netherlands and Luxembourg. The European Economic Community followed in 1957, what is now the EU. Turkey's accession negotiations have been the longest and most difficult of all the waves of enlargement. The negotiations are still in progress.

Regarding the geographical location of Turkey, $95 \%$ of its area is geographically located in Asia, so that the major part of its land is Asian and not European. With regard to its culture, it belongs to the Islamic background. Most of the Turkish population is Muslim, despite its leaders' attempts to get rid of their Islamic culture and background. The rest are others, Christians and Jews. During the reign of Kemal Ataturk (1923-1938), an article was adopted in the constitution, which asserts that "Turkey is a secular and democratic country" and some internal efforts were made in order to get rid of all the eastern and Islamic symbols and traditions, from the organizational structure of the country up to the appearance of citizens in the street. ${ }^{1}$

Turkey applied for membership in 1987, but the application was rejected on the grounds that Turkey suffered at that time from a negative balance of trade and this rejection has been repeated many times within years.

The Turkish persistent desire to join the European Union emerges from its aspiration to benefit economically and militarily. Since Turkey is considered to be a poor country with 60 million people and to have a growing deficit in the balance of trade and a high unemployment rate, the Turkish president TorgutOzal gave some reasons in justification of the bid, in the nineties. He said that Turkey would benefit a lot from joining the European market. The EU would give Turkey the vital energy by providing opportunities through investments in roads, ports, power stations, etc., and in return Turkey would give the European Union a new political, economic and cultural dimension. Turkey would cooperate and share the energy, ability, power and effectiveness of the group. It is clear that from the very beginning Turkey has held some relations with the western group by being accepted as one of the beneficiaries of the Marshal Plan and by being allowed to join the European Council and to become a member of the NATO. Its relationship with Western Europe has been a direct result of the Berlin wall falling and the breakup of the Soviet Union. ${ }^{2}$

Hilal R. Mohammed (1998): “The Turkish membership in the European Union”, The International Politics , 1, 4, 233.

2 Marko J. (2005): “Turkey and Europe: Time for the Truth”, The International Politics, Vol. $159,49$. 


\section{The causes of EU refusal of Turkey's accession bid}

The EU has provided various justifications of the refusal of Turkish request on economic, cultural, national, strategic and internal grounds. There are formal and informal reasons.

The European Union has claimed that the membership conditions and provisions, which are relevant to the case of Turkey, have been the arguments for rejecting Turkey's accession. The key paragraph setting out the Copenhagen criteria stated:

Membership requires that the candidate country has achieved stability of institutions guaranteeing democracy, the rule of law, human rights and respect for and protection of minorities, the existence of a functioning market economy as well as the capacity to cope with competitive pressure and market forces within the Union. Membership presupposes the candidate's ability to take on the obligations of membership including adherence to the aims of political, economic and monetary union.

\section{The economic justifications of refusal}

Turkey is an underdeveloped country and its economic ability cannot follow European economic progress. Turkey's joining The EU would put a load on the EU capital, which is about 16.5-27 billion euro, and there are worries about Turkish membership in terms of lower wages, living standards, and the idea of workers' immigration waves to the member states of the EU. These waves could approximately reach 2.5 million people and lead to many economic, social and political consequences. But facing this economic justification, what could be said about the agreement between the EU and some countries poorer than Turkey, like Eastern Europe countries and the four poor ones before? ${ }^{3}$

In its 2004 'regular report' on accession preparations, the EU lists the reforms that Turkey will have to implement in order to fulfill the two economic criteria, namely a well-functioning market economy and the ability to compete in the single market.

Among other things, the EU is asking Turkey to: cut its budget deficit and make budget planning more efficient; continue to reduce inflation; streamline administrative procedures; strengthen the rule of law; make commercial courts more efficient; sell off state-owned banks and improve financial sector supervision; speed up privatization of state-owned companies and utilities; invest more in education, and tailor it to the needs of a market economy; and make the business climate more attractive for foreign investors.

Helal R. Mohammed, ibid., 240.

Vol. 12, No 3, 2015: 261-276 
In addition, Turkey will have to adopt, implement and enforce EU rules and regulations in 28 areas, including the four freedoms of the single market (the free movement of goods, services, capital and people); agriculture and fisheries; monetary union; transport, energy and telecoms; competition and state aid; policies for small businesses; research, education and culture; consumer protection; environmental rules and foreign and security policy. ${ }^{4}$

\section{The national and cultural justifications}

The European civilization roots extend back to the Greek and Roman Christian inheritance. The refusal to accept relations with Turkey, including 70 million Muslims, whose Ottoman past has been haunting the West ever since the falling of the Eastern Roman Empire in 1453 and the siege of Vienna in 1793, is based on sharp and vast cultural differences. Some EU members express concern about Turkey's joining the European Union as they see it as an improvement for the 25 million Muslims who live in European countries today, while supporting the European Christian conquest once more with $21^{\text {st }}$ century mechanisms. This was reflected in the formal attitude of the Netherlands, refusing to grant the Turkish people the European Union membership and offering the privileged partnership idea instead.

On the other hand, French president Francois Mitterrand openly stated that Europe could not accept an independent Islamic country on the European continent, including Bosnia and Herzegovina as well as Turkey, which strongly seeks to gain European Union membership. This was constantly stated by its constitutional designer, the former French president Valery Giscard d'Estaing, as evidenced by his work towards officially proclaiming Christianity the formal religion of the European Union. Some European countries feared accusations of racism and anti-Semitism, so this affair was abandoned. ${ }^{5}$

\section{Strategic justifications}

The European Union countries feel concern, especially Germany and France, that Ankara government would pose a covert danger of American interference in Europe, designed to stop it from being the major unified international power that could prevent the American pole from controlling the world of the post-cold war era, by using many strategies, such as delaying European economy development through programs and plans of admitting Turkey and other coun-

Barysch K. (2005):The Economics of Turkish Accession, Centre for European Reform Essays, London, 2.

5 Bashir Abdel Fatah (2005): “Turkey, A New Step towards the European Union”, The International Politics, Vol. 163, 191. 
tries which have recently joined the European Union. Moreover, Turkey's joining can extend the borders of European Union membership, reaching deep into the Middle East region with all its chronic and complicated problems and crises that would end the superiority of the European Union and demand much foreign political activity, especially if the European Union interests interfere and clash with the US strategic and vital interests in this area, which is one of the world's most explosive hot spots today.

In this context, the citizens of Turkey within the EU would have unlimited rights of settlement in all other EU countries. By the time of Turkey's possible admission to the EU, the population is projected to increase to 100 million people $^{6}$, which would directly lead to greater representation of Ankara in the European Union parliament, and in turn hinder the unanimity otherwise available regarding certain decisions and attitudes concerning the internal and external policies of the European Union. The European people would not be able to talk with a unanimous attitude on international occasions and the chances of the European Union turning into a major power parallel to the US power would be minimized.?

The former French president Valery Giscard d'Estaing, who was an official of the Union, warned that Turkish accession would be "the end of Europe".

The internal affairs in Turkey are considered to be the most important factors that the European countries rely on to justify their refusal, which are summarized as some violations of human rights by the Turkish government and assaults that the minorities are facing in general (e.g. the Kurdish minority) and the interference of the military in political life.

It is worth mentioning that the European Union insisted on not accepting the Turkish request, perceiving the ability of Turkey to stir problems against the European Union, and its capability to hinder its future plan, for example, by opposing the European Union with the help coming from the North Atlantic alliance in the future. The vital interest of the European Union is to have fewer security tasks than group defense tasks and it cannot work without drawing on the origins and abilities of the alliance. Turkey can respond to any obvious refusal of the request to join the Union by stirring the problems with Greece, either in the Aegean Sea or in northern Cyprus.

\subsection{The Cyprus Issue}

When declaring its independence from the British colonial rule in 1960, the Republic of Cyprus had a constitutional system based on the political equality of Turks and Greeks. Cyprus has been divided since 1974. Greek Cypriots, 76\% of the population, live in the southern two-thirds of the island, Turkish Cypriots, 19\% of

Nugent N. (2005): “Turkey's membership application: Implications for the EU”, Jean Monnet/Robert Schuman Paper Series, Vol. 5, 26.

Bashir Abdel Fatah, ibid., 163. 
the populace, live in the "Turkish Republic of Northern Cyprus" (TRNC), recognized only by Turkey. When the EU officially opened membership negotiations with the Republic of Cyprus in March 1998, a widespread assumption in both the $\mathrm{EU}$ and academic circles was that these negotiations would have a catalytic effect on the Cyprus conflict, helping to bring about a solution that was more or less out of reach for the past decades. ${ }^{8}$ On May $1^{\text {st }} 2004$ Cyprus joined the EU. At their December 2004 summit, the EU leaders agreed to open accession talks with Turkey on $3^{\text {rd }}$ October 2005. One of the conditions specified was for Ankara to extend a 1963 association agreement with the EU predecessor, the European Economic Community, to the Union's ten new member states. This group included the Greek Cypriot state, which is not recognized by Turkey. In July 2005, Turkey signed a protocol extending its customs union to the EU-10 states, but at the same time Ankara issued a declaration saying that its signature did not mean it had recognized the Republic of Cyprus. Turkey also refused to open its ports and airports to Cyprus. ${ }^{9}$

\section{The Turkish internal reaction}

Turkey perceived the insulting and undermining way of dealing shown by the Union and Europe while it sped to do its best to help some countries that have lately got out of communism. Therefore, it was the country that freely chose to approach them and to turn its back to the non-aligned movement that was at the peak of prosperity, which could have been an attractive option for Turkey in the fifties.

On $14^{\text {th }}$ December 1997 the Turkish government decided to stop the political dialogue with the European Union and announced its refusal of the offer presented to it by the Union. The offer was to participate in the European conference held in London in March 1998 to continue the negotiations for the possibility of widening the Union membership. Turkey threatened on $15^{\text {th }}$ December 1997 to withdraw its request for membership if the Union did not abandon its attitude refusing accession to Turkey before the deadline in 1998, and Massoud Yilmaz repeated that threat more than once during his visit to the US on $19^{\text {th }}$ December 1997. The Turkish Prime Minister Erdogan has recently stated that "if the EU does not give the expected go-ahead it will not be difficult for Turkey to channel its huge potential in another direction". He also added that "... a negative response from the EU would both disappoint the Turkish people who have formed its will towards the European values and damage the philosophical basis of the Union irreversibly".

$8 \quad$ Diez T. (2000): Last Exit to Paradise? The EU, the Cyprus Conflict, and the Problematic 'Catalytic Effect', Copenhagen.

9 Turkish Accession and Cyprus, 2007: http://www.euractiv.com/enlargement/turkeyaccession-cyprus-linksdossier-188330 
Due to these events, Turkish government has carried out many reforms inside. On August $8^{\text {th }} 2003$ the seventh European Union reform package went into effect, which liberalized the country's political system, and it took various steps, as follows:

a) The legal and legislative modifications

Various partial modifications, carried out by the Turkish government, were ruled by the adaptive consideration of the Copenhagen's criteria. They were started with the ratification by the Parliament, controlled by the Development and Justice Party, on $3^{\text {rd }}$ July 2003. Furthermore, the modifications depended on accelerating the achievement procedures, suspending citizens' sentences in military courts, shaping public opinion on crimes and teaching the Kurdish language in their schools.

Those reformations included some challenges on behalf of the military establishment and reconstructing the relationship with civil authorities.

According to these reforms, the military budget became subject to Parliamentary censorship. The new legislations undermined the military authority in the National Security Council, which had ruled Turkey covertly, since the military coup in 1980.

b) Reforming the Turkish economy

Since the Justice and Development Party came to power, the Turkish economy has unprecedentedly flourished and become stable. The inflation rate dropped to its lowest level in the last 25 years and the economic performance improved, causing the development rate to reach $5.9 \%$ in 2003 and the individual income level to increase to 3,833 dollars in 2003. The success has also been demonstrated in opening 1,200,000 job opportunities on one hand and in a notable decrease of the inflation rate on the other hand.

Thus, it can be said that the Justice and Development Party appeared serious and insistent in conducting its reformation process required by the Union as a condition to negotiate upon Turkish joining the Union in 2005. In this framework, the action was carried out in two directions:

- The first is the internal democratic reformation aspect.

- The second is the peaceful settlement of the conflict around the Cyprus Island. The government of the Justice and Development Party has been involved in negotiations administrated by the UN aiming at settling the conflict on the island of Cyprus through unifying the parts of the island while guaranteeing Turkish minority rights. The government has shown exceptional flexibility in dealing with this case, hoping to close the Cyprus file, to qualify to join the Union and to normalize its relationship with Greece. 


\section{The Turkish external alternatives}

\subsection{Turkish-US relationship}

Turkey has enhanced the relationship with the US throughout the American-Turkish military cooperation development, embodied in the Turkish purchase of American planes, worth 2.5 billion dollars, and in an agreement to buy 49 more Boeing 737 planes. The US has constantly tried to support Turkey in obtaining the Union membership. For instance, James Foley, a spokesman of the US foreign affairs minister, claimed that "Turkey is a European country that has to be included in the European Union". The Turkish government tries to be friendly with the US in order to make the latter press and persuade the European Union to include Turkey into it.

On the other hand, it cannot be ignored that the current situation is the result not only of a common decision by the member states or just their reaction, but also of continuous political pressure exerted over a long period of time by the United States, both on the EU as a whole and on individual member states to start up negotiations with Turkey. The European uncertainties of today have their origin more in transatlantic than in European-Turkish relations. And they are the result of the inability of the EU states to develop an adequate joint response to US pressure. ${ }^{10}$ The past years have demonstrated yet again that Turkish foreign policy and the dynamics of its formation are of vital interest to American regional interests, be they in the Middle East, Balkans/Aegean, Caucasus, or Central Asia. ${ }^{11}$

\subsection{Turkish-Israeli ties}

Relations between Turkey and Israel have a long and dramatic history, but over time the two countries have reconciled their differences. High-level visits have been introduced on the level of Foreign and Defense Ministers, and Chiefs of the General Staff. Israel is modernizing weapons, planes and tanks, enhancing firepower, maneuverability and electronics, in the largest defense industry deal between Turkey and Israel. In addition, Israeli air force jets were permitted to fly in Turkish air space, when it signed a military agreement in $1996 .{ }^{12}$ Israel shall use its relations to some European organizations and powerful groups to

10 Arnold Hans (2008): "Political Arguments Against the Accession of Turkey to the European Union”, in: Timmerman Christiane, Rochtus Dirk, Mels Sara (eds) $>$ European and Turkish Voices in Favour and Against Turkish Accession to the European Union, P.I.E. Peter Lang, Brussels, 104.

11 Robins P. (2004): "Monterey Suits and Uniforms: Turkish Foreign Policy since the Cold War", Strategic Insights, 3, 4.

12 Pipes D. (1997/98): A New Axis: The Emerging Turkish-Israeli Entente. Daniel Pipes Middle East Forum, http://www.danielpipes.org/293/a-new-axis-the-emerging-turkish-israelientente (12. 3. 2013). 
prepare public opinion and the EU leaders to accept the membership of Turkey in the $\mathrm{EU}$ in the next ten years.

Several factors have pushed Turkey to go for deepened relations with Israel. First, Turkey has been interested in Israeli military technology which Western actors have been unwilling to provide, in light of the Turkish human rights record. Second, the Turkish-Israeli alliance was directed against Syria (and Iran), which at the time supported the Kurdistan Workers Party (PKK). And third, Islamism was perceived as an increasing threat in Turkey, and the alliance was meant to keep Turkey anchored in a Western, secular framework. ${ }^{13}$

- Repairing the cracks in the Arab-Turkish relationships

In recent years, Turkey has turned to the Arab world to strengthen its relationships with the Arab neighbors and to seek its identity and origins. Most Arabs dislike the Turkish-Israeli relationship. The Turkish Foreign Minister announced on $3^{\text {rd }}$ January 1998 that the new attitudes of the Turkish foreign policies toward Israel would be explained and justified to the Arab nations. Egypt, Syria, Libya and the Gulf Cooperation Council countries demanded that Turkey freeze its relationship with Israel so as to develop an economic and cultural relationship between the Arab countries and Turkey. But Turkey refused such a condition and the agreement was declared trial, without the possibility of being ratified in the future. Most Arabs dislike the Turkish-Israeli relationship. The Arab response includes alienation, denial of legitimacy and hostile coalitions.

Rising to power in Turkey, the Justice Party believed that the Turkish-Israeli relationship, characterized by warmth and continuous cooperation, could serve and help in achieving peace and stability in the region, and that it could deepen the role of mediator between Syria and Israel. The economy was the key for developing the Turkish-Arab relationship, bearing in mind the economic crisis faced by Turkey. Consequently, the Arab side's help in solving the problems and direct interests shared with the Arab World improved the situation of Turkey before the European Union. One of the justifications presented by Turkey to join the Union was to form a bridge of harmony between Europe and the Arab and Islamic worlds.

- Forming an alliance between Turkey, Israel and the former Soviet Republics

Turkey improved its relation with those countries after the dissolution of the Soviet Union in 1991. The economic significance of the former Soviet Republics was appreciated after the investment of the American partnership in the oil project. The partnership companies expressed their desire to form a common alliance between American, Turkish and Israeli companies to make use of the Caspian Sea. In this respect, many agreements were negotiated during the visit of Massoud Yilmaz to Ukraine in February 1998. But, this was not all. Ukraine

13 Huber D. (2012): Istanbul Turkish-Israeli Relations in a Changing Strategic Environment. Vol. 12, No 3, 2015: 261-276 
offered Turkey to enter into the Turkish-Israeli military alliance and this offer was greatly welcomed by Turkey, the US and Israel.

Turkey has historically seen Ukraine as a strategic partner. In the years immediately following the demise of the USSR, Ukraine and Turkey similarly had a very close geopolitical outlook in the Black Sea and CIS regions. Ankara backed Ukraine in its Black Sea Fleet dispute with Russia. Ukraine and Turkey signed an intergovernmental agreement in July 1994 on cooperation in the field of military training, technologies and science. The agreement provided the joint training and education of serviceman, exchange of information and joint scientific research in the military sphere. Further agreements on cooperation in their defense industries were signed during the then-President Suleyman Demirel's visit to Ukraine in May 1998. Ukraine has potentially much to gain as well if Turkey is admitted, after a decades-long wait, into the EU. Turkey could certainly become an important Ukrainian lobbyist if the much talked about "strategic partnership" is finally allowed to develop. ${ }^{14}$

\section{The future}

In October 2006, the members of the European Union agreed to re-launch negotiations with Turkey and to prepare to admit Turkey into the Union membership after an identified time. The Turkish people could not reach such an achievement without the persistent attempts and quests and great efforts made by Britain, which chaired the European Union throughout this period. British foreign minister Jack Straw, who supported Turkey's joining the Union, was able to convince the opposing countries to let Turkey gain the Union membership, to persuade Netherlands to grant the Turkish people distinguished partnership instead of full membership and to agree to start negotiations in October 2006. The Turkish people described that as an achievement, based on the previous consistency of the EU refusal to allow Turkey to enter the Christian European club.

At the end, something needs to be said about the information leaking from the European UHNCR, indicating that the negotiations with the Union will not end till 2015, which means that the expected date of Turkey's accession to the Union is 2025 and it is fully logical that by the year 2025 the Union will be dealing with Romania, Bulgaria and Ukraine and maybe many other countries from the Balkan region. The coming years will witness a revival of an organizational balance and cooperation among the member states in the common treasury resource. At the same time Turkey will progress in its economic, political and legal reforms which will attract foreigninvestments and this will facilitate indulgence in the European economy.

${ }_{14}$ Kuzio T. (2002): Toronto Turkish-Ukrainian Relations Receive a Boost. 
Turkey's longstanding relationship with the EU has put the EU in a difficult situation that is best reflected in the following statement of the EU commissioner for Enlargement, Gunther Verheugen: "This decision to accept Turkey was made long ago. For decades, Turkey has been told it has prospects of becoming a full member. It would have disastrous consequences if we now tell Turkey: actually we did not mean this at all". ${ }^{15}$

A future enlargement to include Turkey would be a unique experience for the EU since Turkey will be the only Muslim country. This factor is all the more problematic considering Turkey's large population of 70 million who would join a union that is often referred to as a 'Christian club'. This has created a 'Turcophobia' among some of the Europeans, as was revealed in the statements of the Head of the Convention on the Future of Europe, Valerie Giscard D'Estaing, on the eve of the decision regarding the date for starting accession negotiations with Turkey. He stated that Turkey did not have a place in the EU since "it has a different culture, a different approach, a different way of life'. For these reasons, he claimed that admitting Turkey would be the end of the European Union. ${ }^{16}$

The future of Turkey in the EU is important in its relation to the EU's security environment. Although Turkey acts as a bridge securing the interests of the European countries in the most volatile region of the Middle East, it is the only NATO and Western European Union (WEU) member which is not a full member of the EU.

The EU set a date for Turkey to start accession negotiations in 2005. The decision was primarily taken because of the positive steps taken by Turkey to respond to criticisms of the EU. The EU expressed its satisfaction regarding the fulfillment of the Copenhagen criteria and Turkey's foreign policy towards the Cyprus problem. ${ }^{17}$

\section{Conclusion}

One of the major arguments for Turkish accession is that the reforms Turkey must undergo in order to qualify are precisely those which would result in wider social empowerment, stronger and broader guarantees for personal liberty and a stronger middle class. Turkey's economy has strengthened considerably and their corrupt military has been stripped of its role as a decision making body. In terms of meeting the political aspects of the EU's Copenhagen criteria, the Turkish government has adopted innovative political changes. But, whether Turkey

15 Muftuler Bac (2002a): Enlarging the European Union: Where does Turkey stand?, Tesev Publications, Istanbul,5.

16 For a detailed analysis of the civilization aspects of Turkey's future membership to the EU, see A. Tekin, Future of Turkey-EU relations, Futures.

17 Guney A.(2005): “Ankara The Future of Turkey in the European Union”, Futures 37, 304.

Vol. 12, No 3, 2015: 261-276 
eventually joins the EU is less important than that it finishes its transformation into a vibrant democracy, dynamic economy and admired regional power. ${ }^{18}$

Turkey's membership of the EU will take place only when the international situation allows it. Fulfillment of the Copenhagen criteria does not provide a sufficient motivation for the EU countries to allow Turkey to become a member. The main motivations are concern over oil and competition for transatlantic markets. There are two important reasons why the EU may be interested in full membership for Turkey, the Baku-Ceyhan oil pipeline that will bring the Caspian Sea oil to the Mediterranean through the territory of Turkey, the difficult post-war situation in Iraq and the increasing American control of the Iraqi oil supplies. As the US will have a foot in the Middle East by establishing a firmer presence on Iraqi territory, the EU will have to increase its power in order to cope with American power in these regions and it cannot do it without securing Turkey to its side. Turkey is the only country among the previous thirteen candidates which, despite having applied to the Union the earliest, has not been granted membership. The Turkish membership will not be determined only by the country's ability to meet the accession criteria, but also by specific EU-factors that impact on the Union's approach to Turkey. ${ }^{19}$ The population of Turkey is a great concern on the part of the EU member states. With a voting weight corresponding to its population of nearly seventy million, Turkey will be the second most influential member in the decision-making mechanisms of the EU institutions, especially in the European Parliament and the European Council. The definition of Europe and "Europeanness" has been linked closely to geography, politics and culture and therefore creates problems for some countries, such as Turkey. ${ }^{20}$ The Cyprus question has become closely linked to Turkey-EU relations and is even regarded by some as Turkey's key to the EU. ${ }^{21}$ The EU policy of acting as a catalyst in Cyprus may negatively affect Turkey's bid for EU membership, if Turkey's expectations are not fulfilled by the EU's Cyprus policy in the near future. The eventual acceptance of Turkish membership will be a political decision, and it will depend not only on progress made by Turkey, but also on the political preferences of the EU member governments at the moment of choice. ${ }^{22}$

In the long term, the EU's decision will be more about its own identity and its own future than the eligibility of Turkey. It will decide whether it will face the

18 "Turkey and Europe", The Financial Times, February 13 $3^{\text {th }}$ 2013, http://www.ft.com/intl/ $\mathrm{cms} / \mathrm{s} / 0 / 35$ e75bc0-75f4-11e2-9891-00144feabdc0.html\#axzz2RQgLsPMu (13. 2. 2013).

19 Bac Muftuler (2002b): “Turkey in the EU's Enlargement Process; Obstacles and Challenges”, Mediterranean Politics 7 (2),79.

20 Kahraman S. E. (2000): "Rethinking:Turkey-European Union Relations in the Light of Enlargement", Turkish Studies 1, 1, 6-7.

${ }^{21}$ Ozbilgen F. (2003): Cyprus: Turkey's Key to the EU BIA News Centre, http://www.bianet. org/2004/03/01_eng/news27402.htm

22 Park W. (2000): “European Union Candidacy: from Luxembourg to Helsinki to Ankara?”, Mediterranean Politics, 5, 3, 42-43. 
challenges of an emerging new world; whether it is capable of seizing the new economic, historical and cultural opportunity; whether it can contribute to the embracing of civilizations rather than causing a 'clash' of them. ${ }^{23}$

Although the Copenhagen Criteria are set forth as an important obstacle that will determine the future of Turkey's accession, Turkey's institutional role in the Union's common foreign and security policies, its significant military capabilities and its pivotal geographical position will continue to determine Turkey's strategic importance for the EU in the post-cold war era, due to the former's role in the EU's possible military operations and strategic concerns. Europe requires a stable, modernizing and democratic Turkey to keep radical Islam away from Europe's borders. ${ }^{24}$

Table 1: Turkey in comparison

\begin{tabular}{|l|c|c|c|c|c|c|}
\hline & Turkey & Poland & Spain & Germany & UK & EU-25 \\
\hline Population, million & 72 & 38 & 42 & 83 & 60 & 457 \\
\hline Population in 2050, million & 100 & 32 & 43 & 78 & 67 & 450 \\
\hline GDP, $€$ billion & 240 & 190 & 840 & 2,200 & 1,700 & 10,200 \\
\hline $\begin{array}{l}\text { GDP per head at PPP percent of } \\
\text { EU average }\end{array}$ & 30 & 47 & 98 & 109 & 118 & 100 \\
\hline $\begin{array}{l}\text { Employment as percent of the } \\
\text { Labour force }\end{array}$ & 45 & 52 & 61 & 67 & 72 & 64 \\
\hline $\begin{array}{l}\text { Workers with tertiary education, } \\
\text { percent in 2002 }\end{array}$ & 9 & 13 & 24 & 23 & 27 & N/A \\
\hline $\begin{array}{l}\text { Poverty risk after social transfer, } \\
\text { percent of population 2001-2002 }\end{array}$ & 25 & 17 & 19 & 15 & 19 & 15 \\
\hline $\begin{array}{l}\text { Spending on R\&D, percent of } \\
\text { GDP 2002 }\end{array}$ & 0.7 & 0.6 & 1.0 & 2.5 & 1.9 & 1.9 \\
\hline
\end{tabular}

Sources: Eurostat, United Nations, OECD and Economist Intelligence Unit. Data is for 2004 unless otherwise indicated.

\section{Literature}

- Fatah Abdel B. (2005): “Turkey: A new step towards the European Union”, The International Politics Cairo, Vol. 163

- Barysch, K. (2005): The Economics of Turkish Accession, Centre for European Reform Essays

- Diez, T. (2000): Last Exit to Paradise? The EU, the Cyprus Conflict, and the Problematic 'Catalytic Effect', Copenhagen Peace Research Institute

- Ozbilgen F. (2003): Cyprus: Turkey's Key to the EU BIA News Centre, http:// www.bianet.org/2004/03/01_eng/news27402.htm.

The 'clash' is borrowed from Samuel Huntington's famous work, The Clash of Civilizations.

24 Park W., ibid., 42-43. 
- Guney A. (2005): “Ankara The Future of Turkey in the European Union”, Futures 37

- Hans Arnold (2008): "Political Arguments Against the Accession of Turkey to the European Union, in European and Turkish Voices in Favour and Against Turkish Accession to the European Union", in: Timmerman Christiane, Rochtus Dirk, Mels Sara (eds), P.I.E. Peter Lang, Brussels

- Huber D. (2012): Istanbul Turkish-Israeli Relations in a Changing Strategic Environment Series: IAI Global Turkey in Europe Commentaries, Issue: 5, Istituto Affari Internazionali (IAI), Rome,

- Kahraman S. E. (2000): "Rethinking Turkey-European Union Relations in the Light of Enlargement", Turkish Studies 1 (1)

- Kuzio T. (2002): "Toronto Turkish-Ukrainian Relations Receive a Boost", The Ukrainian Weekly, July $28^{\text {th }}, 2002$, No. 30, Vol. LXX

- Marko J. (2005), "Turkey and Europe - the hour of truth", The International Politics, Vol. 159

- $\quad$ Reda Mohammed Hilal (1998): "Abour The Turkish membership in the European Union", The International Politics, Vol. 1

- Muftuler Bac (2002a): "Enlarging the European Union: Where does Turkey stand?", Tesev Publications, Istanbul

- Muftuler Bac (2002b): “Turkey in the EU's Enlargement Process; Obstacles and Challenges", Mediterranean Politics 7 (2)

- Nugent N. (2005): “Turkey's membership application: Implications for the EU”, Jean Monnet/Robert Schuman Paper Series Vol. 5(26)

- Park W. (2000): "European Union Candidacy: from Luxembourg to Helsinki to Ankara?", Mediterranean Politics 5 (3)

- Pipes D. (1997/98): "A New Axis: The Emerging Turkish-Israeli Entente", Middle East Forum, http://www.danielpipes.org/293/a-new-axis-the-emerging-turkish-israeli-entente (23. 3. 2013)

- Robins P. (2004): "Monterey Suits and Uniforms: Turkish Foreign Policy since the Cold War", Strategic Insights, Vol. 3, Issue 4

- Turkish Accession and Cyprus, 2007, http://www.euractiv.com/enlargement/ turkey-accession-cyprus-linksdossier-188330

Rad primljen: 24. jun 2015.

Paper received: June $24^{\text {th }}, 2015$

Odobren za štampu: 18. septembar 2015. Approved for publication: September $18^{\text {th }}, 2015$ 
Salem A. Dakhil, doktorand

Fakultet za međunarodnu ekonomiju,

Univerzitet „Džon Nezbit“ (Megatrend univerzitet), Beograd

\section{PRISTUPANJE TURSKE EVROPSKOJ UNIJI}

\section{S a ž e $\mathbf{t}$ a k}

Rad daje kratki pregled procesa pristupanja Evropskoj uniji i put Turske ka njenom članstvu. Cilj istraživanja je da izvesti o statusu pristupnih pregovora Turske. Autor postavlja pitanja koja treba da rasvetle ovaj proces koji još uvek traje. Istraženi su značajni razlozi zbog kojih Turska nastoji da se pridruži Evropskoj uniji, uzroci stalnog odbijanja Evropske unije, unutrašnja reakcija Turske, spoljne alternative kojima je turska strana pribegla i budućnost pristupanja Turske Evropskoj uniji.

Ključne reči: dalje proširenje Evropske unije, reforme, Turska, Evropska unija 